Article

\title{
An Ethical Ideal? Louise Rosenblatt and Democracy-A Personalist Reconsideration
}

\author{
Richard Vytniorgu \\ Department of English, University of Leicester, Leicester LE1 7RH, UK; richard.vytniorgu@my365.dmu.ac.uk
}

Received: 2 February 2018; Accepted: 14 March 2018; Published: 21 March 2018

check for updates

\begin{abstract}
Louise Rosenblatt's theory of literary experience was a landmark in twentieth-century contributions to aesthetics, pedagogy, and literary theory. Her work is consistently studied, although critical re-evaluations have waned in the past ten years or so. This essay turns to Rosenblatt's political commitment to democracy and argues that in her writing, her politics are in conflict with her more personalist sympathies concerning the value of the human being. I draw on the philosophy of personalism to show how Rosenblatt's writing on imagination offers a more congenial framework for thinking about building harmonious human relations.
\end{abstract}

Keywords: Louise Rosenblatt; personalism; democracy; phantasm; Berdyaev; ethics; literary imagination; Maxine Greene

\section{Introduction}

In her fifth edition of Literature as Exploration, the renowned American theorist of literary experience, Louise Rosenblatt, then aged ninety-one, once again affirmed the crucial relationship between the reading of literature and democracy. "Democracy and literature," she wrote, "take on a special relevance to education for the contemporary world" (Rosenblatt 1995, p. xv). When, in 1938, she published the first edition of Literature as Exploration, democracy was being threatened most obviously by totalitarian administrations in Europe, Russia, and Japan. But even by the time of the fifth edition, in 1995, Rosenblatt felt the need to stress the urgency with which democracy needed to be safeguarded. Alive to the changes in American society that took place in the forty years after World War Two, Rosenblatt was aware that democracy might be threatened by increases in ethnic and cultural diversity without an explicit adhesive bond being actively cultivated at the same time. Such a bond, she felt, could be created by a certain kind of literary studies in the schools and colleges which was explicitly connected to an open vision of American democracy-a way of bringing groups together under a common banner.

Due in part to the various interviews Rosenblatt undertook in the 1980s and 1990s, as well as the prefaces in the re-publications of Literature as Exploration and her more theoretical work, The Reader, the Text, the Poem: The Transactional Theory of the Literary Work (Rosenblatt 1994), and the introduction to her essays in Making Meaning with Texts: Selected Essays (2005), Rosenblatt is well-known among educators, critics, and theorists for being committed to a vision of American democracy. When Ann E. Berthoff wrote in her essay, "Democratic Practice, Pragmatic Vistas," that "Louise Rosenblatt makes me proud to be an American," she was highlighting Rosenblatt's interest in Whitman's democratic vision, for the reading and studying of literature as a vivifying force in cultivating democratic American citizens (Berthoff 1991, p. 84). Still more enthusiastic is Gordon M. Pradl, whose Literature for Democracy: Reading as a Social Act (1996), argued for the need "to indoctrinate openly the basic concepts of a democratic system" in the English classroom (Pradl 1996, p. 87). Pradl's book was clearly inspired by Rosenblatt, echoing her own title, Literature as Exploration, and his voice is sympathetic to her ethical commitments. More recent 
critics have also highlighted Rosenblatt's vision of democracy and the role of English studies in furthering this end. Jeanne M. Connell (2005) has focused on Rosenblatt's debt to the pragmatist philosopher, John Dewey (one of Rosenblatt's heroes), and in her 2007 article for College English, Elizabeth A. Flynn presented a reconsideration of Rosenblatt as a literary theorist interested in literature "as a moral and ethical force, helping readers clarify their values and allowing them to share the values of others"-foundational to a democratic system (Flynn 2007, p. 67).

My purpose here is to continue a reconsideration of Rosenblatt's work by offering a more critical analysis of her interest in democracy than we have seen so far. Critical studies on Rosenblatt have generally waned over the last ten years or so, most likely because, while Rosenblatt's texts are still taught in the classroom, her work has now passed into a canon of English pedagogical landmarks - suitable for study, but saturated in terms of critical evaluation. Meanwhile, in the past twenty years additional theories of reader response have arisen which complement but offer a different focus to Rosenblatt's transactional theory, such as narrative transportation theory, bibliotherapy (Morawski and Gilbert 2008), cognitive poetics and text world theory (Gavins 2007), and critical literacy (Misson and Morgan 2006). There is an understandable temptation to contextualize and contain Rosenblatt's work as firmly mid-century, concerned with the need to shift from transmission models of English education to process approaches, championed by the 1966 Anglo-American Conference at Dartmouth (Smagorinsky 2002).

However, when we turn to the intersection of Rosenblatt's political concerns and her literary theory, there seems to be a challenge which requires further consideration-one which nuances our understanding of Rosenblatt's legacy as well as intersecting with more recent theories of reader engagement with texts. I find myself questioning the necessity, which Rosenblatt clearly felt, to lock literary studies within an overtly political project of safeguarding democracy, even if, for rhetorical purposes, Rosenblatt may have felt in the 1950s that it was a logistical necessity if nothing else, to ensure that literary studies moved beyond the distinctly undemocratic goal of eliciting the author's one-and-only true meaning. In this essay, I argue that Rosenblatt's theory of literary experience, which lies at the heart of her scholarly work, contains the seeds of a more personalist project of developing harmonious human relations, especially in multicultural societies-although, as I explain, the term "multiculturalism" is a loaded one in Rosenblatt's later work, best discarded in favor of "pluralism." In short, where Rosenblatt saw the need to import a political system and its commitments into her literary theory, I am suggesting that her aesthetic theory, sans democracy, can be robust enough to reach similar ethical ends, without risking the dangers inherent in subordinating a theory to a political ideal such as democratic formation.

To begin with, I shall outline the development of Rosenblatt's commitment to democracy and her response to multiculturalism in the 1990s, while also evaluating the work of one of her most devoted critics, Gordon Pradl, who further advanced the cause of literary studies (à la Rosenblatt) in the service of democracy. I will then critique this insistence on democracy as the ultimate justification of literary studies by turning to the existential philosophy of personalism, as advocated by one of the most insightful of personalist philosophers-the twentieth-century Russian thinker, Nikolai Berdyaev. As Jan Olof Bengtsson states in The Worldview of Personalism: Origins and Early Development, personalism is a multinational philosophy which began in Germany in the 1780 s as a reaction to pantheism, and insists on the person as the key to reality (Bengtsson 2006, p. 67). Berdyaev is particularly illuminating for the purposes of this essay, given his rooting in an existentialist tradition interested in personality as an axiological principle.

Personalism differs from humanism, which is also interested in people, in its focus on the microcosmic world of concrete persons as opposed to humankind in general. To be personalist is to take a singular, rather than a universal, approach to human beings. Personalism also benefits from its openness to religious discourses of human being and conceptions of interpersonal communion. Berdyaev's voluminous writing, for the most part now available in English, is committed to 
communicating the importance of personality, creativity, and interpersonal growth and their rootedness in freedom. Consequently, anything which threatens personality and interpersonal contact is critiqued.

In this essay, I am most interested in Berdyaev's concept of the phantasm as that which constitutes an abstraction to which human persons can be subjected. I argue that as Rosenblatt presents it, democracy becomes a phantasm - a phantasm to which people can be subordinated. In the third part of the essay, I will focus on Rosenblatt's writing on imagination and seek to frame this as a more personalist vision of human relations in transactional English studies, freed from the dogmatism (and phantasm) of a political system.

My use of the term "ethical" in this essay is based on Flynn's assessment of Rosenblatt's ethical position. For Flynn, the ethical in Rosenblatt's work can be found in her emphasis on "the humanness of both authors and readers. They are not constructs but people" (Flynn 2007, p. 55), and also in her encouragement to readers "to be reflective about how they are living their lives" (Flynn 2007, p. 57). Affirming Rosenblatt's approximation to Lawence Buell's concept of "postpoststructuralism," Flynn reads Rosenblatt as a theorist whose political concerns intersected with these broader ethical ones (Flynn 2007, p. 54). My contention in this essay is that for Rosenblatt, her vision of democracy is at root an ethical ideal, although it manifests in an overtly political discourse. I want to retain an interest in Rosenblatt's ethical commitments while critiquing her idealism, which finds expression in her politics.

\section{Rosenblatt's Commitment to Democracy}

Rosenblatt's commitment to democracy developed from an early age, and morphed over the decades by responding to wider social currents. In her 1982 interview for Columbia University conducted by Ed Erwin, Rosenblatt explained how her commitment to democracy was instilled from an early age, growing up in a household permeated by antiauthoritarian ideas. Named after the nineteenth-century French anarchist, Louise Michel, Louise Michelle Rosenblatt was born in 1904 in New Jersey to Russian-Jewish immigrant parents who were committed to a libertarian approach to life, emphasizing "the importance of the individual and the need for the individual's right to develop freely and fully" (Rosenblatt 1982, p. 3). The Russian anarchist writer, Emma Goldman, was invited to the Rosenblatts' house in Atlantic City, New Jersey, around 1910. "I did read Emma Goldman's essays [in high school]," Rosenblatt admitted, "and I did read these libertarian articles" and Goldman's writing on European writers such as Hauptmann, Wedekind, Tolstoy, Dostoyevsky, and various dramatists (Rosenblatt 1982, p. 15). In short, as she stated in 2001 at the Great Women Scholars meeting in New York, "I grew up with the whole idea that no matter what your gender or your race, or your creed, or your religion, or whatever it might be, everybody was entitled to life, liberty and the pursuit of happiness" (Garn Press 2015).

As she told Erwin, in the years following the First World War, she came to connect her commitment to the individual to a "belief that you had to change people's imaginations, you had to change their ideas, their attitudes towards others" (Rosenblatt 1982, p. 40). If change for the good was going to happen in society-if people were going to get along with each other better-then finding a route into the imagination was key. "I had this feeling," said Rosenblatt, "and I suppose it was expressed best by Shelley who said that 'the poets are the legislators of mankind' because they change, they influence people's imaginations and that is what really guides behavior, the ability to put oneself in another person's place, to understand the implications of your choices, human implications" (Rosenblatt 1982, p. 40). In 1920 this was the reason she gave her father for specializing in literature at Barnard College, and in recalling this incident at the Great Women Scholars meeting, she effectively re-affirmed her commitment to Shelley's romantic vision of literature. Although it is true that Rosenblatt began her academic career in the late 1920s in Paris by writing a French doctoral thesis in comparative literature that focused on writers, shortly after this she began to turn her attention more vigorously to readers and the way their imaginations might be engaged in the experience of literary works of art, for the furtherance of American democracy. 
In the 1930s, Rosenblatt's commitment to democracy became more overtly channeled through her academic work and her political activism: indeed, the two were intimately connected. As she recalled in 1977, in 1938 she published her hugely popular work completed on the rebound from her time spent with the Progressive Education Association's Commission on Human Relations, Literature as Exploration, and shortly after this she was invited by the former president of the National Council of Teachers of English, Dora V. Smith, to address an audience of thousands of English teachers, on 23 November 1939, at the old Manhattan Opera House in New York-an address which was also broadcast on the radio. In her 1977 reminiscences Rosenblatt connected this speech, which reflected on the value of English education, to her political campaigning for reformist figures, whereby she had "pounded the streets and rung doorbells" (Rosenblatt 1977, p. 88). Rosenblatt explained that nationally, she and her father, Samuel, initially supported Norman Thomas of the Socialist Party of America, but with the crisis of the Great Depression both shifted their support to Franklin D. Roosevelt as they felt his policies could address the situation better (Rosenblatt 1982, p. 138). Throughout her adult life, Rosenblatt typically evaluated national and local politics on the basis of long-term foresight, and whether policies were imbued with feeling for the human consequences of decisions-feeling she felt was supremely cultivated by the kind of literary studies she advocated, which, as I shall show in due course, placed considerable emphasis on the personal, aesthetic experience of the human aspect of literary works.

It was only after her official retirement date in 1972, though, that Rosenblatt turned her attention more explicitly to relating her commitment to democracy to the changes that had taken place in American society since the end of the Second World War. In 1978 she published her essay for Yale Review, entitled "Whitman's Democratic Vistas and The New 'Ethnicity'," which was reprinted in Making Meaning with Texts. This essay sought to bring Walt Whitman's commitment to a pluralistic American democracy into the present day by critiquing a new emphasis in the wider culture on ethnic origins. Singling out Whitman's concern for "the autonomous worth and uniqueness of the individual human being," which clearly aligns with her own guiding star, Rosenblatt then questioned the implications of the term "ethnicity," and asked whether there "is [... ] room for the new ethnicity in Whitman's view of the state as an aggregate whose prime justification is that it creates the stable environment within which the individual can freely and fully develop?" (Rosenblatt 2005, pp. 144, 151). Or, focusing more explicitly on the recent interest in personal roots, Rosenblatt also asked whether Whitman's "concern for individuals joined in the solidarity of American nationality rule[s] out the current quest for a narrower solidarity based on ethnic roots and ethnic memories?" (Rosenblatt 2005, p. 151). Rosenblatt's overriding concern in this article is to position democracy as the political system and ideology which best serves the interests of the individual.

In order to help theorize her position in 1978, Rosenblatt turned to the work of the American philosopher, Horace M. Kallen, whose theory of "cultural pluralism" enabled her to keep democracy as the overarching goal of a particular model of ethnic relations that avoided the seclusion of such groups within enclaves. Although Kallen wrote an article for Rosenblatt's 1946 edited issue of The English Journal, entitled "Of the American Spirit," (Kallen 1946) his theory of cultural pluralism is discussed here only obliquely. But his idea is in fact very simple, and, as Rosenblatt's husband, Sidney Ratner, wrote in 1984, it primarily aimed to supplant the assimilationist, White Anglo-Saxon Protestant (WASP) model of Americanization popular in the 1910s, encapsulated in the metaphor of the melting pot. According to Ratner, at the heart of Kallen's theory is a concern for the individual, and that the individual should be allowed and given the resources to develop freely and fully. Democracy was believed to be the political system most adept at safeguarding conditions in which the individual could develop. But in order for democracy to flourish, different cultural groups in America needed to work together, largely through conversation, towards creating the conditions of unity in which diversity could grow. The new metaphor became one of an "orchestration" of "differents," retaining their distinctiveness, but playing to the tune of American democracy (Ratner 1984, p. 187). 
Rosenblatt advanced the cause of cultural pluralism in her unwavering faith in democracy as the unitive force embracing diverse Americans. Taking Whitman's cue, she honored an individual's right to ethnic and cultural identification and self-creation, but she also urged that cultural cross-pollination is a healthy and positive trait in Americans. Again, Rosenblatt managed to find a way of bringing politics back to her engagement with English studies and its potential vivification of the imagination, and vice versa, so that if she is talking about English studies, politics are never far away, and if she's talking about politics, a return to an English studies context can be expected. The advance of American democracy gave Rosenblatt a clear objective for her literary theoretical work, and cultural pluralism provided her with a model of human relations which she could import into her work, answering the "why" regarding the importance of fostering imaginative capacity in learners.

Towards the end of the century, Rosenblatt's faith in cultural pluralism remained strong and by 1999 she was self-consciously distinguishing it from multiculturalism, which she saw as "too limited because [students] should also be helped to value other backgrounds" (Rosenblatt 1999). The confidence with which she then says in this interview for the University of Miami, "of course the unity [which binds society together] is democracy," reveals her unwavering belief in the sovereignty of the individual and the appositeness of democracy to safeguard such sovereignty, against its erosion by enclaves (Rosenblatt 1999). Rosenblatt therefore differs from contemporary multiculturalist theorists such as the British political theorist Bhikhu Parekh (2000), in that she tends to see ethnic self-containment as a danger to American democracy, whereas Parekh sees monocultural enclaves within a broader multicultural society in a fairly neutral, even positive light. Invoking Whitman, Rosenblatt says that the individual is more than his ethnic label: "He must be free to make his own choices, to seek out his own friends, to enter freely into other associations, other groups" (Rosenblatt 2005, p. 152). It is the "aggressive withdrawal" of groups in which lies "the danger of an intensification of differences, the danger of competition, of separatism, of conflict" (Rosenblatt 2005, pp. 153-54). With the increasing popularity of multiculturalism as a term not only to describe social reality in the United States, but also as a normative position praising ethnic and cultural differences, Rosenblatt returned repeatedly to an older model of cultural pluralism because it more obviously served the ultimate goal of democracy; in her eyes, multiculturalism could not. But before I offer a critique of Rosenblatt's commitment to democracy, I must turn to Gordon Pradl's continuation and extension of Rosenblatt's work, because Pradl beats the drum of democracy with perhaps even more enthusiasm than Rosenblatt, and he certainly translates the principle of democracy more obviously into the dynamics of the English classroom.

As a one-time student of Rosenblatt's at New York University in the 1960s, and latterly as a colleague and friend, Pradl knew both Rosenblatt and her work intimately. His essay for John Clifford's edited volume, The Experience of Reading: Louise Rosenblatt and Reader-Response Theory (1991), focuses explicitly on Rosenblatt's democratic impulse and was sent in draft form to Rosenblatt for comment (Pradl 1991), while his own text, Literature for Democracy (Pradl 1996), uses Rosenblatt's work as a theoretical basis for his own exploration of classroom dynamics. Part of the rationale behind Pradl's essay is to detach Rosenblatt from the label of reader-response; all the essays in Clifford's volume emphasize the differences between Rosenblatt's transactional approach and subjectivist (or more individualistic) approaches to literary studies developed by theorists such as David Bleich and Norman Holland. Built into Rosenblatt's vision, argues Pradl, is a constant emphasis on classroom discussion about aesthetic, personal experiences of literature, leading to democratic discussion about human values that are personally vivifying for the individuals in question, which is not simply an intellectual exercise. What Pradl achieves in this book is a pedagogic model, inspired by Rosenblatt, which builds democracy into its very core.

Pradl's tone seems much warmer than Rosenblatt's typical one; his solicitude for democracy is at times touching. He writes that "Rosenblatt fears for the fragility of democratic social arrangements, which our selfish human temperament always seems on the verge of disrupting or tearing apart" (Pradl 1996, p. 76). Indeed, Pradl even admits that 
Like most, I will never be completely predisposed to democracy; someone is always playing their music too loudly and I go mad. Faced with the demands and adjustments of social living, I often want it all to go away. I want to live in the present, with my bearings fixed and secure [ ... ] I get tired of arguing with everyone who disagrees with me. Can't we just do it my way? (Pradl 1996, p. 6, original emphasis).

This is a revealing admission. One feels that Rosenblatt would never expose herself so nakedly in print. For Pradl, democracy is so crucial because he knows it does not come naturally to human beings. All the more reason, therefore, to highlight Rosenblatt's challenge

to indoctrinate openly the basic concepts of a democratic system. Working explicitly on the basis of democratic principles helps to defend students from being subtly indoctrinated with negative attitudes toward our society. It preserves students' freedom to make up their own minds about what to accept and what to reject. (Pradl 1996, p. 87)

Pradl's goal is to influence actual teaching. There are many passages in Literature for Democracy which give case studies of student engagement with texts, and instances of where teachers subtly guide students to particular interpretations, thus modelling a kind of authoritarian epistemology, whereby students come to know what they know because they follow the authority of the teacher, who will feel insecure if he or she does not feel in charge.

For Rosenblatt and especially for Pradl, human relations, especially in a diverse society characterized by multiple backgrounds and allegiances, can only be developed fruitfully by casting them in the mold of a democratic system. It is not because I dismiss the substance of the insights into literary studies developed by Rosenblatt and Pradl that I wish to question their faith in democracy. On the contrary, it is because I think such insights are pregnant with possibility, for truly bringing personalities together in a culture of diversity, that I wish to offer a critique.

\section{The Phantasm of Democracy}

The central problem with advocating a vision of "literature for democracy" is that, as seems quite clear in the writing of Rosenblatt and Pradl, students (human persons) are put in the service of an abstract ethical ideal-a political concept of democracy. Of course, the immediate response to this would be to say that democracy is a way of life, inculcating habits of behavior and attitudes and so on. To invoke Louis Althusser, we might say that people willingly interpellate themselves as democratic subjects, whereby habits of conversation and the majority vote hold sway in order to keep the peace. In colloquial parlance, we can say that we know democracy when we see it: the bossy are kept in check, the shy and timid are given a voice, the excluded are included, and so on, and we can never be satisfied with the status quo. The difficulty arises, however, when these practices, fine in themselves, are pinned to the label of democracy, which is then made to do more work than these practices in themselves are able to do. Democracy becomes a political rallying cry, a banner of truth, a cause worth living for, even something to die for. As Rosenblatt stated in 1982, being named after Louise Michel meant that being "a leader and an achiever" who "fought on the barricades and so on" was "part of my image of myself" (Rosenblatt 1982, pp. 25, 39-40). But such fighting runs the risk of taking up human energies which might otherwise be spent on increasing our capacity to show ethical acts of kindness to others and on weeding out destructive emotions and behaviors. In other words, an emphasis on literature for democracy runs the risk of taking us away from human beings and their inner worlds-precisely the locus of attention Rosenblatt and Pradl are ostensibly concerned to amplify. Democracy becomes a phantasm to which human persons are subjected.

The existentially inflected philosophy of the Russian personalist thinker, Nikolai Berdyaev (1874-1948), is keenly aware of the danger of phantasms. According to Berdyaev in his hugely popular work, The Destiny of Man (1945), "Phantasms are destructive in their results, they destroy and pervert realities and lead from being to non-being" (Berdyaev 1945, p. 180). A phantasm is essentially a bad fantasy - something which takes us out of the inner, concrete world of human beings and projects 
something abstractly as a cause worth investing in with passion. To put it another way, such passions "create phantasmagorical worlds of their own, [and] destroy man's sense of reality and make him an idealist in the bad sense of the term" (Berdyaev 1945, p. 180).

Berdyaev is coming from a theistic and existentialist tradition which sees the person as the highest worth; he is a personalist. According to Keith E. Yandell in the Routledge Encyclopedia of Philosophy (Yandell 1998), personalism

develops a worldview that begins with immediate, self-conscious experience and interprets not only the life of the individual but the world at large in personalistic terms. This involves the claim that the basic categories or fundamental concepts of our thought should be understood in terms applicable to persons and their experiences.

Berdyaev seeks to foreground the human person-the human subject-and the world of personal experiences, emotions, and relationships. Against this he pits the abstract, objectivized world which detracts attention away from persons. A phantasm moves the focus away from persons towards an ideal which is created and propounded with such vigor that its promotion returns human beings from being to non-being - a term Berdyaev regularly employs to describe an existential abyss. Principle among phantasms singled out for criticism by Berdyaev is capitalism:

The lust of greed and love of money for its own sake creates one of the most fantastic worlds, furthest removed from the real world of being - the world of capitalism, of banks, stock-exchanges, paper money, cheques, IOU's, advertisement, competition and pursuit of easy gain [ ... ] Léon Bloy was right in saying that finance is a peculiar kind of mystery-play. (Berdyaev 1945, pp. 182-83).

Capitalism offers a clear example of the dynamics of a phantasmagorical world that is clearly systematized; its paraphernalia mark its status as a systemic phantasm. But as Berdyaev notes, other ideals can become phantasms too; Lenin succumbed to one with his Bolshevik dream. The essential quality of phantasms is that they "always enslave the spirit" (Berdyaev 1945, p. 183). Phantasms have a characteristically debilitating impact on human beings, even if it might not always be obvious. "A man who strives to realize some utopian idea at all costs," wrote Berdyaev, "may be entirely disinterested and guided by moral motives, since he strives for the perfect life, but he is self-centred and may become a moral idiot, losing the power of distinguishing between good and evil" (Berdyaev 1945, p. 182). Berdyaev is making an ethical incision in conventional beliefs: what seems perfect may be otherwise; what seems politically expedient may in fact be counterproductive. Those who are struggling for a passionate ethical ideal, especially a political one, may become dulled to more intimate moments of personal encounter. As Berdyaev explains in Slavery and Freedom (Berdyaev 1944), the future triumphs over the present, and the end justifies the means.

Even in her nineties, as Rosenblatt explained to Nicholas Karolides in a 1999 interview reprinted in Making Meaning with Texts, her "tendency, as always, is to dwell, not so much on rewards for past efforts, no matter how much appreciated, as on what remains to be done" (Rosenblatt 2005, p. xvii). The "current problems and controversies" Rosenblatt keenly observes around her become fuel to her future-oriented, cleansing fire (Rosenblatt 2005, p. xvii). Her final preface, to Making Meaning with Texts, which retrospectively constitutes a farewell letter "To My Readers," was written on 15 September 2004, and sealed her rationale for "Fostering a critical approach to all writings, no matter what their point of view," because this would, "I believed, serve their advancement of democracy" (Rosenblatt 2005, p. ix). Even at this final stage of her life and career, she was holding high the banner of a democratic future.

We do not need to subscribe to Berdyaev's Christianity to work with his concept of the phantasm. But I would argue that the broad qualities of phantasm are evident in Rosenblatt's disinterested passion for democracy. Yes, she seems "guided by moral motives, since [s] for the perfect life," redolent with democratic vigor, but has she unnecessarily subordinated her interest in the growth of human persons to an ethical ideal of democracy which too easily 
becomes phantasmagorical? (Berdyaev 1945, p. 182). Reading Rosenblatt's work, especially Literature as Exploration, one might be forgiven for thinking that Rosenblatt is trying to mold particular types of human being. Indeed: she is. With her beloved democracy always before her, students in English disciplines are required to develop habits of thought and particular values attached to a democratic system. They are required to develop these because if they do not, then the lives of others may be in jeopardy. The logic of Rosenblatt's pluralism is that one is always creating the conditions in which others can thrive (ostensibly as well as one's self). The problem is that the human person and his or her growth, which Rosenblatt champions, is effectively deferred. Objectified within the phantasm of democracy, learners in Rosenblatt's literary theory can be forgiven for sensing that their experiences—-their sense of self-are seconded to somebody else-the mysterious beneficiary of democracy, always "out there."

The nineteenth-century Russian religious and personalist thinker, Vladimir Solovyov, put it well when he wrote that "as soon as we put alongside of the natural primary basis of all rights an artificial one, citizenship, there open up wide possibilities of declaring this or that group of men to be in a special position as citizens, or rather, as not-citizens, and of depriving them of all human rights under the pretext that those rights belong to citizens only" (Solovyov 2001, p. 52, original emphasis). Solovyov's point reminds us that as a phantasm, democracy tends to evaluate people based on their quality of citizenship and how much they contribute to the democratic cause. But this requires a necessary division of people who may be living in the same space, between citizens and non-citizens. The existential person is vulnerable to being objectified as a socialized, political subject.

The philosopher Isaiah Berlin reiterated a similar point in the 1950s by turning to the thought of the nineteenth-century Russian thinker, Aleksandr Herzen. Herzen may well in fact have influenced Berdyaev in his antipathy towards abstract concepts of humanity in general. What Berlin (via Herzen) emphasizes and brings into the twentieth century, however, is the persistent danger of concentrating on abstract ideas about humanity, often humanistic, at the expense of attention and care for the concrete, existential human (Berlin 1994). Personalists like Berdyaev, in The Destiny of Man, invoke Jesus's words that the Sabbath was in fact made for man rather than the other way around, that man is made for the Sabbath (which the Pharisees propounded); which means that concepts which organize society in some way should be managed so that they serve actual people (Berdyaev 1945, p. 107). With Rosenblatt the danger is that learners, explicitly conceived as citizens in the making, are put in the service of an abstract, future-oriented vision of democracy and cultural pluralism. Fixated as she is by an ethical necessity to be political in her literary theory, Rosenblatt effectively locks the development of healthy human relations within a phantasmagorical world of a democratic system. In her writing, students are made and re-made as citizens for democracy.

The irony, or perhaps even tragedy, of all this is that I do not think Rosenblatt's literary theory requires the overarching democratic vision; she is ethical enough without it, and I shall now show why. As Rosenblatt's personal narrative makes clear, her commitment to democracy was profoundly influenced by forces essentially extrinsic to her theoretical work. From the 1920s when she entered college until her final years, Rosenblatt seemed haunted by her father's political example and inspiration. As she wrote in her 1938 preface to Literature as Exploration, "My debt to my father's concern for social values cannot be adequately acknowledged" (Rosenblatt 1938, p. ix). The positive development of human relations, especially in a pluralistic society such as late-twentieth-century America, could only occur, in Rosenblatt's eyes, via the subordination of everything to the furtherance of the democratic ideal. I have shown, however, that personalists, who are often coming from a non-secular background, point out the dangers for the human person of such passionate political idealism. The personalist response is to return to the concrete, present world of the person and his or her ethical relationships with others. What I want to show now is that in Rosenblatt's writing on literary imagination, she in fact approximates a personalist approach to human relations in literary studies. Indeed, I suggest that it is her writing on imagination that is more significant, in the long-term, 
for negotiating interpersonal contact in the context of transactional literary studies, than her writing on the necessity for democratic development.

\section{Literary Imagination and Interpersonal Contact}

Rosenblatt's transactional theory, set out in full in her work, The Reader, the Text, the Poem: The Transactional Theory of the Literary Work, should continue to be recognized as a major achievement in literary theory, foreshadowing yet still holding its own among more recent theories interested in the way a reader makes meaning with texts. As Pradl rightly maintains in Literature for Democracy, Rosenblatt's "dismantling of the reader/text distinction [ ... ] solved the problems that later reader-response critics used in part to build their careers in academia" (Pradl 1996, p. 84). The change in epistemology which the transactional vision effects allowed Rosenblatt to "set aside 'the very question that fueled [a] decade of reader-response critical theory: is it the reader or the text that determines interpretation?'" (Pradl 1996, p. 84).

Moreover, Rosenblatt's transactional theory succeeds because it is properly integrated into pedagogy. For Rosenblatt, the reading of literature, at least as literary theory usually envisages it, always happens in an institutional, educational context in which readers are also positioned as learners. This means that the reading of literature is simultaneously the study of literature, which cannot escape from questions concerning the value of such study in the wider society. And it is at this point that Rosenblatt's writing on imagination comes into its own. But this was not simply a theoretical exercise. In delineating the contours of literary experience, Rosenblatt was making the case for the role of literary imagination in bringing people together-to evaluate ways of life, and to encourage individuals to grow as personalities. The transactional stance places significant emphasis on the processes of selection readers engage in to make meaning personal to them. As Literature as Exploration makes clear, literary experiences allow readers to think rationally about human complexities within an emotional context. Following Dewey, Rosenblatt affirmed that true learning occurs only when learners are emotionally invested in something. For knowledge to be assimilated and made operative in someone's life, there has to be an emotional connection of some sort, from which the selective attention of rational thinking proceeds. Recent narrative transportation theory also affirms the role of emotion in being transported in the experience of a story, while also explaining that different people will experience different levels of emotional engagement-a variable such theorists refer to as "transportability" and one's "need for affect", which is personality dependent (Green and Fitzgerald 2017, p. 5).

This is why, for Rosenblatt, the aesthetic experience of literature was so important to develop as a pedagogical practice in literary studies: out of this matrix arises constructive thinking about existentially significant issues which truly matter to the individual learners in question. In Literature as Exploration Rosenblatt could therefore claim that "Literary experiences will then be a potent force in the growth of critically minded, emotionally liberated individuals who possess the energy and will to create a happier way of life for themselves and for others" (Rosenblatt 1995, p. 262). But in what sense exactly can imagination in Rosenblatt's work push literary experiences in the direction of (inter)personal growth? The answer lies in how Rosenblatt frames the value of literature-or the particular affordances of transactional literary experiences.

In Literature as Exploration Rosenblatt declares that "no matter what the form-poem, novel, drama, biography, essay-literature makes alive and comprehensible to us the myriad ways in which human beings meet the infinite possibilities that life offers" (Rosenblatt 1995, p. 6). She is keen to highlight "the human value, the human experience, that literature presents" (Rosenblatt 1995, p. 8). These statements come after an almost lyrical passage on literature's potential to evoke human experiences, reminiscent of the conclusion to her PhD thesis, in which her critical voice emerges by aligning herself with earlier defenders of the value of literary art, in this case the Italian philosopher, Benedetto Croce, and the Russian novelist, Leo Tolstoy:

For is not the subject-matter of literature everything that man has thought, or felt, or created? The lyric poet utters all that the human heart can feel, from joy in "the cherry hung with snow" 
to the poignant sense of this world "where youth grows pale, and spectre-thin, and dies." The novelist sets forth the intricate web of human relationships with their hidden pattern of motive and emotion [ ... ] The writer of stories catches some significant moment, some mood, some clarifying clash of wills in the life of an individual or a group [ ... ] The dramatist builds a dynamic structure out of the tensions and conflicts of intermingled human lives [ ... ] The joys of adventure, the delight in the beauty of the world about us, the intensities of triumph and defeat, the self-questionings and self-realizations, the pangs of love and hate-indeed, as Henry James has said, "all life, all feeling, all observation, all vision"—-these are the province of literature. (Rosenblatt 1995, pp. 5-6).

Rosenblatt was especially fond of quoting this line from Henry James. By including references to Keats and A. E. Housman in the same breath, so to speak, she tacitly invokes a kind of literature, largely romantic, which is especially amenable to the kinds of literary experiences she thinks are most pregnant with questions concerning human existence. Furthermore, Rosenblatt singles out the roles of different kinds of artists because she sees these individuals as offering a service for other human beings. This is a subtle reordering of priorities in literary studies, away from attention heavily directed towards the author or the stylistics of a text as ends in themselves, toward a sense of literature serving readers in a more personal, experiential, and ethical way. As with Walter Pater and Oscar Wilde before her, Rosenblatt is everywhere trying to assert the agency of the reader, and the ways in which literature might energize the inner life of the student.

By establishing the province of literature for the purposes of literary studies, Rosenblatt was able to present her case for the importance of literary imagination with greater persuasion. For Rosenblatt, imagination lies at the core of literary experiences which reach the heart of what literature affords us as human beings in quest of meaning that can give shape to our lives together. It is therefore appropriate to speak of "literary imagination" as that which is conditioned by the transactional literary experience. Importantly, imaginative participation in literary experiences can increase learners' understanding of lives and experiences alien to their own.

For instance, literary experiences may lead to growth in empathetic attitudes-what Suzanne Keen in her study, Empathy and the Novel (2007), refers to as the "affective transaction across boundaries of time, culture, and location" (Keen 2007, p. xxv). According to Rosenblatt, "books are a means of getting outside the limited cultural group into which the individual is born. They are, in a sense, elements of societies distant in time and space made personally available to the reader" (Rosenblatt 1995, p. 192). Of course, not all books depict life in a remote place or time, so rather than a dualism of "here" and "there" and even one of "I" and "them," Rosenblatt's general thrust is toward a continuum, entirely focused on the specific transaction between actual readers and actual texts. And, as narrative transportation theorists remind us, some "individuals tend to enjoy and seek out situations that allow them to experience strong emotions, whereas individuals low in need for affect prefer to avoid emotional-evoking situations" (Green and Fitzgerald 2017, p. 5). The question then becomes, of course, whether literary studies can increase a person's need for affect and transportability, not just in the aesthetic experience of narratives, but in a wide variety of aesthetic experiences with a range of stimuli.

In her 1940 essay, "Moderns Among Masterpieces," reprinted in Making Meaning with Texts, Rosenblatt declares the benefit of studying the "classics" to be in their ability to offer "new insights" applicable to a reader's "contemporary" society (Rosenblatt 2005, p. 108). A reader should be nurtured to be "alive in the truest sense, not cut off from the world about them, but aware of the conflicting currents of thought and feeling, the unsolved problems, the new visions struggling to be born" (Rosenblatt 2005, p. 108). Rosenblatt seems to advocate a dialogic relationship between self and other-not an utter and radical difference between reader and fictional world, or even between "classic" and "contemporary" - but rather a porous borderland with scope for identification as well as amplification. She deftly avoids polemic about the canon by re-framing the debate from the perspective of actual readers: who are they? What will help them become the kind of readers she has in mind-sensitive, critical, and evaluative? Although critical literacy builds its foundations on 
premises other than transactional ones, it is a contemporary approach to literary pedagogy which shares Rosenblatt's concern for the specifics of individuals' learning contexts and the need to be actively engaged and critical of self and the world at large. Where some critical literacy theorists also emphasize the crucial role of the aesthetic in building a critical orientation to life, Rosenblatt's transactional theory is built more explicitly on a particular aesthetic, pragmatist philosophy that grows out of a deeper understanding of human existence in the world (Misson and Morgan 2006).

Rosenblatt's learners are implicitly learners in quest-existential subjects becoming aware of themselves as developing personalities in transaction with a wider environment. At its best, this is a resolutely personalist and existential vision of literary studies, in tune with the kind of arts education set forth by the American existentialist philosopher Maxine Greene, who in fact studied under Rosenblatt at Barnard in the 1930s, if only for one module. Greene's work is deeply preoccupied with the nature and value of imagination, and she too frames the value of the arts in stirring awakenings in concrete individuals, but does so more urgently, yet without allowing her ethical ideals to morph into a phantasmagorical political vista. In a 1979 essay for College English Greene wrote of her concern about "encounters with imaginative literature as they advance the search for meaning that goes on throughout life," and this theme is fully explored in Releasing the Imagination: Essays on Education, the Arts, and Social Change (2000), by combining personal reflections with literary criticism and philosophical speculation (Greene 1979, p. 133). In this text Greene speaks of seeking "shocks of awareness" and initiations into "uneasy participation in the human community's unending quest" (Greene 2000, p. 151). Imagination, so precious to Greene, is the key by which people can, in an echo of Dewey, break through the "inertia of habit" (Greene 1979, p. 21).

New possibilities can emerge if a breakthrough occurs-when "a person chooses to view herself or himself in the midst of things, as beginner or learner or explorer, and has the imagination to envisage new things emerging, more and more begins to seem possible" (Greene 2000, p. 22). Greene colors this perspective by quoting Emily Dickinson's poem: "The possible's slow fuse is lit/By the Imagination." For Greene, the possible's slow fuse is lit especially by a form of imagination which brings the human person into communion with others, which can help her or him to join others in their quests. "Imagination may be a new way of decentering ourselves," she writes, "of breaking out of the confinements of privatism and self-regard into a space where we can come face to face with others and call out, 'Here we are'” (Greene 2000, p. 31).

Greene's commitment to imagination is so compelling because she refuses to tie its possibilities to a political ideal. As an existentialist concerned with the growth of individual persons in concert with each other, Greene is more interested in witnessing those moments of ethical breakthrough, where personalities which are often marked by difference are brought into contact in such a way that vision is transformed and social change seems possible. She is careful not to idealize the nature of this social change, however. Instead, she speaks in intimate tones of coming "face to face with others" and being able to call out "Here we are" (Greene 2000, p. 31). Greene can be placed in a cluster of other thinkers, including Martin Buber and Emmanuel Levinas, who focus especially on those moments of human contact, particularly face-to-face contact but other forms as well, that can be profoundly transformative in the deepest of ways.

The point is not that a personalist perspective ignores the social aspect; it manifestly does not. Rather, personalism refuses to erect an ideal as the sun to which all life must turn; it refuses to create the conditions in which persons become enslaved to phantasms, even if such phantasms are originally caused by "good intentions" and the desire to inaugurate the "perfect life." Rosenblatt's ethical impetus is not being questioned here: it is at the kernel of her theory and pedagogy, and flowers in her writing on imagination. But her commitment to a democratic vista tugs at this flowering, threatening to uproot imagination from concrete existential encounters and toss it to the winds of a political phantasm. In such a scenario, learners are conditioned as citizens to serve a mysterious beneficiary of democracy; their personal growth is deferred to others, rather than occurring in a truly interpersonal way. 


\section{Conclusions}

To sum up: although Rosenblatt's work was primarily in the domain of literary theory and English education, she never wavered in linking this theoretical work to a broader position on democracy and the role of literary studies in serving democracy. Inspired in part by her family upbringing and her experience of the turbulent 1930s and the Second World War, Rosenblatt firmly believed that democracy should be at the core of any consideration of America's future. For Rosenblatt, democracy was an ethical ideal of human understanding across differences, which could, via literary study, be instilled among policy and decision makers. The emphasis was on building bridges, on creating a pluralistic society, and avoiding retreat among minorities into ethnic enclaves. Literary studies, done Rosenblatt's way, positions aesthetic experience as a pathway to growth in democratic attitudes, such as imagining the human consequences of attitudes and behavior. In other words, the aesthetic, experiential component of the humanities is made to do special work for Rosenblatt; it is not merely a pleasant occurrence, or even something broadly instructive in the Horatian sense, but the very thing that should jolt learners into conversation with one another, via literary texts, about life issues and how to build a better way of life for oneself and for others. Such learners, might, in turn, become the future politicians, writers, and thinkers of a democratic American future.

In this reconsideration of Rosenblatt's interest in democracy I have, however, questioned the ethical merits of her passionate and idealistic vision, showing how, from a personalist perspective, such idealism runs the risk of creating a phantasm which may generate damaging effects for actual persons. I have emphasized the strengths of Rosenblatt's writing on imagination, which develops organically from her transactional theory of the literary work. In her own reconsideration of Rosenblatt's work, Elizabeth Flynn talks of "the process of rereading" Rosenblatt (Flynn 2007, p. 68). For many teachers of English, Rosenblatt will be a name associated with the transactional approach, with aesthetic and efferent reading placed on a continuum of reading stances. She will be known for her advocacy of process approaches to literacy and literary studies-a jewel in a cluster of educationalists which includes names like James Squire, James Britton, and David Holbrook (among others). Some will remember her for her connection to twentieth-century luminaries such as Margaret Mead, Gregory Bateson, Ford Madox Ford, Léonie Adams, and many others besides. Others will recall her indebtedness to the pragmatist philosophers, John Dewey, Charles Sanders Peirce, and William James. Some, of course, will think of her as a champion of American democracy, and will have read her as prophet, a Whitmanian literatus. It is because her work remains so dear to many educators, critics, and theorists, that this reconsideration—this rereading—of Rosenblatt's interest in democracy has been launched.

In Rosenblatt's writing on imagination the kernel of her interest in democracy is revealed. Invoking Shelley, she focuses on the need for individuals to think of others-to use their imagination to feel with others. As Flynn has argued, Rosenblatt certainly participates in an ethical turn in literary theory. But personal growth and social change are more unpredictable and existential than Rosenblatt gave obvious credit for; they cannot readily be pinned to an ideal of democracy. Such ethical desires are personalist ones, focusing on the fundamental worth and singularity of each human person. This love for oneself and for others as concrete personalities in the making cannot be systematized or indoctrinated. The literary experience and the transactional classroom, sans the indoctrination of democracy, can then become an arena for learners' entrance into Greene's "uneasy participation in the human community's unending quest" (Greene 2000, p. 151). This is the real gem of Rosenblatt's legacy—a truly ethical moment in literary theory.

Acknowledgments: I wish to thank Gordon Pradl for reading an earlier draft of this essay and for offering advice and encouragement. I would also like to thank Elizabeth Flynn for her long-standing support of my rereading of Rosenblatt.

Conflicts of Interest: The author declares no conflict of interest. 


\section{References}

Bengtsson, Jan Olof. 2006. The Worldview of Personalism: Origins and Early Development. Oxford: Oxford University Press. Berdyaev, Nikolai. 1944. Slavery and Freedom. Translated by R. M. French. London: Geoffrey Bles.

Berdyaev, Nikolai. 1945. The Destiny of Man. Translated by Natalie Duddington. London: Geoffrey Bles.

Berlin, Isaiah. 1994. Russian Thinkers. Harmondsworth: Penguin Classics.

Berthoff, Ann E. 1991. Democratic Practice, Pragmatic Vistas: Louise Rosenblatt and the Reader's Response. In The Experience of Reading: Louise Rosenblatt and Reader-Response Theory. Edited by John Clifford. Portsmouth: Boynton/Cook, pp. 77-84.

Connell, Jeanne M. 2005. Continue to Explore: In Memory of Louise Rosenblatt. Education and Culture 21: 63-79. Flynn, Elizabeth A. 2007. Louise Rosenblatt and the Ethical Turn in Literary Theory. College English 70: 52-69.

Garn Press. 2015. Great Women Scholars Part Three: Louise Rosenblatt. Available online: http:/ /garnpress.com/ 2015/great-women-scholars-part-three-louise-rosenblatt/ (accessed on 3 August 2016).

Gavins, Joanna. 2007. Text World Theory: An Introduction. Edinburgh: Edinburgh University Press.

Green, Melanie C., and Kaitlin Fitzgerald. 2017. Transportation Theory Applied to Health and Risk Messaging. Oxford Research Encyclopedia of Communication, 1-24. [CrossRef]

Greene, Maxine. 1979. Language, Literature, and the Release of Meaning. College English 41: 123-35. [CrossRef]

Greene, Maxine. 2000. Releasing the Imagination: Essays on Education, the Arts, and Social Change. San Francisco: Jossey-Bass.

Kallen, Horace M. 1946. Of the American Spirit: An Open Letter to Teachers of English. The English Journal 36: 289-94. [CrossRef]

Keen, Suzanne. 2007. Empathy and the Novel. Oxford: Oxford University Press.

Misson, Ray, and Wendy Morgan. 2006. Critical Literacy and the Aesthetic: Transforming the English Classroom. Urbana: NCTE.

Morawski, Cynthia M., and Jenelle N. Gilbert. 2008. Bringing Louise Rosenblatt into the content areas: Transacting in interactive bibliotherapy. English Quarterly 38: 4-15.

Parekh, Bhikhu. 2000. Rethinking Multiculturalism: Cultural Diversity and Political Theory. Basingstoke: Palgrave Macmillan.

Pradl, Gordon M. 1991. Reading Literature in a Democracy: The Challenge of Louise Rosenblatt. In The Experience of Reading: Louise Rosenblatt and Reader-Response Theory. Edited by John Clifford. Portsmouth: Boynton/Cook, pp. 23-46.

Pradl, Gordon M. 1996. Literature for Democracy: Reading as a Social Act. Portsmouth: Heinemann.

Ratner, Sidney. 1984. Horace M. Kallen and Cultural Pluralism. Modern Judaism 4: 185-200. [CrossRef]

Rosenblatt, Louise M. 1938. Literature as Exploration. New York: Modern Language Association.

Rosenblatt, Louise M. 1977. What We Have Learned: Reminiscences of the NCTE. The English Journal 66: 88-90. [CrossRef]

Rosenblatt, Louise M. 1982. The Reminiscences of Louise Michelle Rosenblatt. Interview by E. Erwin. New York, NY, USA.

Rosenblatt, Louise M. 1994. The Reader, the Text, the Poem: The Transactional Theory of the Literary Work. Carbondale: Southern Illinois University Press.

Rosenblatt, Louise M. 1995. Literature as Exploration, 5th ed. New York: Modern Language Association.

Rosenblatt, Louise M. 1999. Louise Rosenblatt Interview. Interview by E. F. Provenzo. Miami, FL, USA, March 14. Rosenblatt, Louise M. 2005. Making Meaning with Texts: Selected Essays. Portsmouth: Heinemann.

Smagorinsky, Peter. 2002. Growth through English Revisited. The English Journal 91: 23-29.

Solovyov, Vladimir. 2001. A Solovyov Anthology. Edited by S. L. Frank. London: Saint Austin Press.

Yandell, Keith E. 1998. Personalism. In Routledge Encyclopedia of Philosophy. Edited by E. Craig. London: Routledge.

(C) 2018 by the author. Licensee MDPI, Basel, Switzerland. This article is an open access article distributed under the terms and conditions of the Creative Commons Attribution (CC BY) license (http:/ / creativecommons.org/licenses/by/4.0/). 